\title{
Lessons from a Vaccine Contract
}

\author{
Samir Malhotra
}

Journal of Postgraduate Medicine, Education and Research (2021): 10.5005/jp-journals-10028-1454

This is the story about a vaccine contract that one of the world's largest countries known for its beautiful beaches, wonderful waterfalls, tropical rainforest, carnivals, and football, entered into with one of the world's largest pharmaceutical companies. There is no point in naming them as this article argues about some of the important clauses in the contract, which have serious implications for all of us.

In theory, if someone suffers injury due to a drug, they can approach the courts for compensation by suing the manufacturer. In practice, causation is difficult to establish, and the courts ask for evidence of negligence. To overcome this, many countries established clauses like a strict liability when compensation may be provided without the need to demonstrate fault.

This was the case for vaccines as well. Here, we are talking about the USA. Probably, the first vaccine-related injury compensation of $\$ 200,000$ was given in 1970 when the court ordered the vaccine manufacturer to pay the family of a girl who had developed postvaccination polio. Soon similar claims were being made for other vaccines and pharma companies were paying millions of dollars annually to settle the claims. Since this was hurting their business, some pharma companies began to move away from vaccines to other fields during the late 1970s and early 1980s.

The US government responded by deciding to indemnify the pharma companies-with the passage of the National Childhood Vaccine Injury Act, 1986, and the Vaccine Injury Compensation Program. ${ }^{1}$ Under the new law, the vaccine buyers had to pay an additional tax on the purchase of a vaccine, and the Compensation Program was to be funded from this. The burden of compensation was thus passed from the industry to the people. Such transfer of wealth from people to a select few was an uncommon practice in those years, but now occurs widely-over the past 5 to 6 decades, nearly $\$ 50$ trillion of wealth transfer has occurred from the bottom $90 \%$ of Americans to the top $1 \% .^{2}$

The COVID-19 vaccines were developed at an extremely rapid pace, shrinking the clinical new drug development process from 7 to 8 years to approximately a year. The COVID-19 scare forced many governments to enter into contracts with the companies developing vaccines. Many of these contracts had confidentiality clauses, but one, which is the topic of this article, became public. According to this contract, the company was exempted "from any civil liability for serious side effects arising from the use of the vaccine, indefinitely". As stated above, the companies had won this battle with the people in the late 1980s.

In our institution, while discussing clinical trial agreements, we often insist for the court of jurisdiction be India and not a foreign country. Not in this case-the court had to be of the company's home country and would be convened secretly, in case of disputes. ${ }^{3}$

Juan Branco, a French political activist, tweeted ${ }^{4}$ this contract in August 2021, after which people took notice. Here is a sample of the language of the contract:
Department of Pharmacology, Postgraduate Institute of Medical Education and Research, Chandigarh, India

Corresponding Author: Samir Malhotra, Department of Pharmacology, Postgraduate Institute of Medical Education and Research, Chandigarh, India, Phone: +91 7087008598, e-mail: smal.pgi@gmail.com

How to cite this article: Malhotra S. Lessons from a Vaccine Contract. J Postgrad Med Edu Res 2021;55(4):153-154.

Source of support: Nil

Conflict of interest: None

"Purchaser hereby agrees to indemnify, defend and hold harmless [the company and] each of their affiliates from and against any and all suits, claims, actions, demands, losses, damages, liabilities, settlements, penalties, fines, costs and expenses caused by, arising out of, relating to, or resulting from the vaccine."

Sweeping as this language might seem, this is usual stuff. But then an interesting detail crops up. According to the contract, with this country and some others, the company demanded that these countries must provide a guarantee, by creating a new fund, in a foreign bank, that will indemnify the company against future litigations, occurring due to adverse reactions to the vaccine. Not only that, and this is shocking, these countries should "put up sovereign assets as collateral to guarantee indemnity". 5 Such assets could include embassy buildings, cultural assets, etc. The necessity and non-negotiability of this clause stem from the fact that the development of the vaccine had occurred at such a fast pace that the probability of detecting new adverse reactions, or in special populations, ${ }^{6}$ in the future was quite high, and this is a risk they are unwilling to take.

Such clauses and ensuing negotiations delay or altogether deny countries' procurement of vaccines-this has deadly consequences for the people, but is of little consequence for the manufacturers. In the past few decades, the pharma industry has paid billions of dollars in fines for various malpractices like kickbacks and misbranding, ${ }^{7}$ manipulating studies and suppressing negative results, ${ }^{8}$ co-payment fraud, ${ }^{9}$ withholding evidence and false advertising, ${ }^{10}$ failure to report safety data, ${ }^{11}$ using "great deceivers" in clinical trials, ${ }^{12}$ among others. But this is much bigger than fraudthis is blackmail of countries by super-powerful, supranational corporations, taking advantage of a worldwide calamity, keeping profit above people.

The pharma industry often quotes the high costs of new drug development to justify such contracts and prices of drugs but fails to acknowledge that virtually $100 \%$ of initial research leading to new drugs occurs with the support of public funding. ${ }^{13}$ In this case, the company had also claimed that they received no government funding, which was untrue-while the government of one country

(OThe Author(s). 2021 Open Access This article is distributed under the terms of the Creative Commons Attribution 4.0International License (https://creativecommons. org/licenses/by-nc/4.0/), which permits unrestricted use, distribution, and non-commercial reproduction in any medium, provided you give appropriate credit to the original author(s) and the source, provide a link to the Creative Commons license, and indicate if changes were made. The Creative Commons Public Domain Dedication waiver (http://creativecommons.org/publicdomain/zero/1.0/) applies to the data made available in this article, unless otherwise stated. 
had provided $\$ 445$ million, another had pre-ordered vaccines worth $\$ 2$ billion.

The outrageous one-sidedness of the contract is also highlighted by some of the other clauses like no penalty for delayed supply, or no claim of negligence if a faulty vaccine is delivered. The strict confidentiality clause also points to the fact that neither the company nor the government prefers to share this with the public. A vaccine that requires a few dollars to manufacture has brought in profits worth billions of dollars to the company, ${ }_{1}^{14}$ of which the company is fighting hard not to lose.

Even in the advanced countries, governments are either unwilling to resist the big pharma, or are unable to, or, at worst, are in collusion with the companies. That the US FDA, widely considered to be the benchmark among regulatory authorities, has been accused of burying the evidence of scientific misconduct it detects, ${ }^{15}$ or was willing to work behind the scenes to approve products without sufficient evidence ${ }^{16}$-all of which does not instill a great deal of confidence, but has occurred in other fields as well. ${ }^{17}$

That we are better placed in our country due to the manufacturing capacity built over the past century does not absolve us from debating such unilateral contracts. The companies have refused to share the vaccine technology, despite requests from the WHO and several countries. ${ }^{18}$ The power amassed by the grotesquely rich, oligopolistic companies working with a single-minded aim of profit-maximization, even at the cost of human lives, must be curtailed if the world healthcare system has to fulfill the promise of the Alma Ata Declaration. One might note many similarities of how our societies responded to pandemics in the past ${ }^{19}$ with the current, ${ }^{20}$ but the massive profiteering ${ }^{21}$ clearly is unique to our times. There should be no doubt about the significant contribution of the pharma industry in providing new drugs, but "At What Cost," 22 as the state of healthcare in many countries, including developed ones, is increasingly being called "broken"! 23,24

Names are being deliberately withheld as the purpose here is to raise the issue, without pinpointing any particular entity, all the more because most, if not all, indulge in similar practices. The audacity of the contract teaches us, warns us, and I hope, prepares us for the future, to collectively strategize-search for alternative systems or discover entirely new ones.

\section{References}

1. https://www.hrsa.gov/vaccine-compensation/about/index. html\#: :text=The $\% 20$ National\%20Childhood\%20Vaccine $\% 20$ Injury,be\%20injured\%20by\%20certain\%20vaccines. Accessed 18.09.2021.

2. Price, Carter C, Edwards KA, Trends in Income From 1975 to 2018. Santa Monica, CA: RAND Corporation, 2020. https://www.rand.org/ pubs/working_papers/WRA516-1.html. Accessed 19.09.2021.
3. https://www.theguardian.com/global-development/2021/sep/10/ pfizer-accused-of-holding-brazil-to-ransom-over-vaccine-contractdemands. Accessed 19.09.2021.

4. https://twitter.com/anatolium/status/1430162378692382733?s=20. Accessed 11.09.2021.

5. https://www.thebureauinvestigates.com/stories/2021-02-23/held-toransom-pfizer-demands-governments-gamble-with-state-assets-tosecure-vaccine-deal. Accessed 11.09.2021 .

6. Høeg TB, Krug A, Stevenson J, et al. SARS-CoV-2 mRNA vaccinationassociated myocarditis in children ages 12-17: a stratified national database analysis. MedRxiv 2021.21262866. [Preprint] https://www. medrxiv.org/content/10.1101/2021.08.30.21262866v1.

7. https://www.justice.gov/opa/pr/justice-department-announceslargest-health-care-fraud-settlement-its-history. Accessed 19.09.2021.

8. https://www.reuters.com/article/us-pfizer-neurontin-settlementidUSKBNOED1IS20140602. Accessed 18.09.2021.

9. https://www.justice.gov/opa/pr/gilead-agrees-pay-97-millionresolve-alleged-false-claims-act-liability-paying-kickbacks. Accessed 19.09.2021.

10. https://www.corp-research.org/astrazeneca. Accessed 18.09.2021.

11. https://www.justice.gov/opa/pr/glaxosmithkline-plead-guilty-andpay-3-billion-resolve-fraud-allegations-and-failure-report. Accessed 19.09.2021.

12. Abbasi K. The next step in immorality: charging to create and cure disease. BMJ 2021;374:n2268. DOI: 10.1136/bmj.n2268Accessed 18.09.2021.

13. Galkina EC, Beierlein JM, Khanuja NS, et al. Contribution of NIH funding to new drug approvals 2010-2016. Proceed Nat Acad Sci 2018;115(10):2329-2334. DOI: 10.1073/pnas.1715368115.

14. https://www.nytimes.com/2021/05/04/business/pfizer-covidvaccine-profits.html. Accessed 11.09.2021.

15. https://slate.com/technology/2015/02/fda-inspections-fraudfabrication-and-scientific-misconduct-are-hidden-from-the-publicand-doctors.html. Accessed 19.09.2021.

16. https://www.bloomberg.com/news/articles/2021-06-22/internaldocuments-reveal-fda-clash-over-alzheimer-s-therapy. Accessed 12.09.2021.

17. https://doi.org/10.20529/JMME.2021.064. Accessed 12.09.2021.

18. https://science.thewire.in/health/public-health-must-be-thehighest-law/. Accessed 12.09.2021.

19. Snowden F. Epidemics and society: from the black death to the present. Yale University Press; 2019. p. 682. \$35 (hardcover), ISBN 978-0-300-19221-6.

20. https://ijme.in/articles/pandemics-as-mirrors-of-society-the-morethings-change-the-more-they-stay-the-same/. Accessed 12.09.2021.

21. https://science.thewire.in/health/covid-19-big-pharma-taxpayerfunded-development-profiteering/. Accessed 12.09.2021.

22. Freudenberg N. At what cost. Modern Capitalism and the Future of Health. USA: Oxford University Press; 2021.

23. https://www.theguardian.com/us-news/2020/apr/16/profit-overpeople-cost-over-care-americas-broken-healthcare-exposed-byvirus. Accessed 12.09.2021.

24. Rosenthal E. An American sickness. How American healthcare became big business and how we can take it back. New York: Penguin Press; 2017. 